\title{
Kemampuan Mengenal Huruf Pada Anak Usia 5-6 Tahun Di Perumahan Guru Kecamatan Kotabumi Selatan Kabupaten Lampung Utara
}

\author{
Destri Rachma Pratiwi ${ }^{1)^{*}}$, Rizky Drupadi ${ }^{1)^{*}}$, Ulwan Syafrudin ${ }^{\text {1* }}$ \\ ${ }^{1}$ FKIP, Universitas Lampung, Jl. Prof. Dr. Sumantri Brojonegoro No. 1 \\ E-mail: destrirahmap123@gmail.com
}

Received: 21 Oktober 2020

Accepted: 4 November 2020

Published: 10 November 2020

Abstract. The Ability To Recognize Letters in Children Aged 5-6 Years Old at Teacher Housing, Sub-District South Kotabumi, District North Lampung. The purpose of this study is to describe the ability to recognize letters of early childhood. Subjects were selected using technique namely purposive sample. The study used 8 subjects, namely the children 5-6 years old, there are 18 people consisting of 7 boys, 8 girls, and 3 parents. This study uses observation and interviews to collect data with an analysis process through three stages, namely data reduction, data display, and conclusions and data verification. Based on the results of observations and interviews with research subjects, it is concluded that based on the results of the percentage of observations that show the ability to recognize letters of children aged 5-6 years of 15 children who were observed to reach a percentage of 77\%-98.9\% which states that the child is in the very good category. From the results of the interview with 3 parents, it can be concluded that the ability to recognize letters is one of the most basic or initial stages before the child enters the reading stage, in introducing letters through the reading method that does not give a burden to the child must be done by learning activities using play so that the activity becomes fun.

Keywords: the ability to recognize letters, children aged 5-6 years old

Abstrak. Kemampuan Mengenal Huruf Pada Anak Usia 5-6 Tahun Di Perumahan Guru Kecamatan Kotabumi Selatan Kabupaten Lampung Utara. Tujuan penelitian ini untuk mendeskripsikan kemampuan mengenal huruf anak usia dini. Subjek dipilih menggunakan teknik sampel yaitu purposive sample. Pada penelitian ini menggunakan 8 subjek yaitu anak-anak berusia 5-6 tahun sebanyak 18 orang yang terdiri dari 7 orang anak laki-laki, 8 orang anak perempuan, dan 3 orang tua. Penelitian ini menggunakan observasi dan wawancara untuk mengumpulkan data dengan proses analisis melalui tiga tahapan yaitu reduksi data, display data, dan kesimpulan serta verifikasi data. Berdasarkan hasil observasi dan wawancara dengan subjek penelitian disimpulkan bahwa berdasarkan hasil presentase observasi yang menunujukkan kemampuan mengenal huruf anak usia 5-6 tahun dari 15 anak yang diobservasi mencapai presentase 77\%-98,9\% yang menyatakan bahwa anak tergolong ke dalam kategori sangat baik. Dari hasil wawancara dengan 3 orang tua dapat disimpulkan kemampuan mengenal huruf merupakan salah satu tahapan paling dasar atau awal sebelum anak memasuki tahapan membaca, dalam mengenalkan huruf melalui metode membaca yang tidak memberikan beban kepada anak harus dilakukan dengan kegiatan pembelajaran dengan menggunakan bermain sehingga kegiatan menjadi menyenangkan.

Kata kunci: kemampuan mengenal huruf, anak usia 5-6 tahun 


\section{PENDAHULUAN}

Setiap orang yang terlahir ke dunia pada dasarnya mempunyai potensi dan kemampuan yang sama, hanya bagaimana anak mampu melalui proses pendidikan di lingkungan yang berbeda, menyebabkan potensi yang dimiliki anak satu dengan yang lain mengalami perbedaan. Semua akan tergantung bagaimana lingkungan pendidikan, keluarga, dan lingkungan masyarakat yang mengarahkan. Anak merupakan bagian dari individu yang sedang mengalami perkembangan dengan sangat cepat dan menjadi bagian mendasar dalam memberikan kontribusi serta pengaruh untuk kehidupan anak selanjutnya. Menurut Berk (Sujiono, 2008) anak pada masa ini sedang mengalami suatu proses yang berhubungan dengan perkembangan juga pertumbuhan dirinya, dalam hal ini berbagai aspek perkembangan dan pertumbuhan yang dimiliki oleh anak mengalami masa yang sangat cepat perubahan dan perkembangannya dalam rentang kehidupan seorang individu untuk mengalami perubahan.

Kehidupan masa perkembangan anak yang memiliki usia 0-6 tahun merupakan masa perkembangan yang sangat cepat serta menjadi dasar pada awal tahun kehidupannya, dimana proses yang akan dialami oleh anak menunjukkan pada proses perkembangan kearah masa yang tidak akan dapat diulangi dan menjadi tahap yang sempurna serta mengalami peyempurnaan dalam setiap pembelajaran sesuai stimulus yang akan anak terima. (Khadijah, 2016). Maka, stimulus yang diberikan sejak usia dini mempengaruhi perkembangan anak dimasa selanjutnya, pada usia ini anak dalam masa keemasan (golden age) khususnya ketika usia 5-6 tahun, Dalam
(Kemendikbud, 2014) yang membahas tentang Kurikulum Pendidikan Anak Usia Dini, dinyatakan anak akan mengalamiperkembang secara maksimal dan baiksangat perlumemperhatikan berbagai aspek yang dimiliki anak seperti aspek kognitif, sosial-emosional, moralagama, fisik-motorik, seni, dan juga bahasa, dalam mengembangkan berbagai aspek yang dimiliki maka harus disesuaikan dengan kurikulum menyesuaikan pada konteks bermain kepada anak usia dini. Sehingga, dalam mengembangkan berbagai potensi yang akan dimiliki oleh anak, maka harus dilaksanakan menggunakan berbagai kegiatan belajar, kegiatan tersebut dapat dikemas secara kreatif serta menyenangkan melalui permainan ketika pembelajaran untuk anak.

Program pembelajaran yang baik untuk anak berusia 0-6 tahun sebaiknya dikembalikan kepada sistem pembelajaran dengan mengajak anak untuk bermain, melalui bernyanyi, memberikan anak kesempatan untuk dapat bergerak secara bebas, serta memberikan kesempatan kepada anak agar mereka dapat melakukan percobaan dan kreasi agar imajinasi yang anak miliki dapat tersalurkan dan dikembangkan dengan secara baik, dalam pembelajaran juga harus memberikan kenyamanan dan kesan yang menyenangkan kepada anak, sehingga dengan semua hal tersebut diharapkan seluruhaspek perkembangan yang seharusnya dimiliki oleh anak yangdisesuaikan dengan tiap tahapan usia anak, dari berbagai perkembangan yang dimiliki anak salah satu tahapan penting dalam perkembangan anak usia dini yang harus dikembangkan secara baik yaitu perkembangan bahasa anak. Perkembangan yang akan dialami oleh anak merupakan bagian terpenting untuk diperhatikan, perkembangan seperti 
bahasa pada anak menjadi salah satu perkembangan yang seharusnya diperhatikan dengan teliti, sehubungan dengan perkembangan anak pada bahasa menurut Otto dalam (Rahayuningsih et.al., 2019) bahasa terbagi dua jenis yaitu bahasa tulis dan bahasa lisan, bahasa lisan merupakan bahasa yang dalam penyampaiannya dilakukan secara langsung atau secara lisan, sedangkan bahasa tulis dalam penyampaiannya dilakukan secara tidak lisan melalui tulisan.

Menurut Cochrane Efal dalam (Mislahusnika, 2016) dalam setiap tahap dan proses perkembangan anak untuk membaca, anak akan mengalami beberapa tahapan, seperti pertama tahapan imajinasi (magic stage), tahapan kedua anak akan mengalami tahap (self concept stage) atau tahap pembentukan konsep dirinya, tahap ketiga anak akan memasuki tahap (bridging reading stage) atau sering disebut tahap membaca gambar, tahapan keempat yang akan anak alami merupakan tahap mengenal bacaan (take-off reader stage), serta tahap terkahir anak akan mampu membaca secara (independen reader stage) sehingga pada tahap ini anak sudah memiliki kemampuan membaca dengan lancar. Dari seluruh tahapan yang ada, maka dapat ditarik kesimpulan anak berusia 5-6 tahun semestinya sudah memasuki tahap mampu membaca gambar sesuai dengan Peraturan Menteri Pendidikan dan Kebudayaan 146 Tahun 2014 menyebutkan bahwa anak sudah mampu menunjukkan bentuk simbol sebelum menulis (pra menulis) serta anak sudah mampu menunjukkan dan menghasilkan beberapa hasil karya seperti menghasilkan karya gambaran yang terdapat beberapa coretan serta tulisan di dalamnya, dan anak sudah mampu membentuk huruf dan kata pada karyanya.
Kemampuan mengenal huruf dalam (Nursalam, 2016 \& Fallis, 2013) yaitu sebuah kegiatan yang akan melibatkan pendengaran (auditif) dan unsur pengamatan (visual). Anak mulai mengenal huruf dimulai saat anak mulai senang mengetahui banyak buku, anak mulai mengamati, tertarik memegang, mulai membolak-balik halaman buku, mulai meminta untuk dibacakan buku cerita kepada orang tua.Mengajarkan bunyi huruf, simbol huruf kepada anak usia dini menurut Lisnawati dalam (Nursalam, 2016 \& Fallis, 2013) dapat dilakukan menggunakan cara menyatukan setiap bunyi menggunakan gerak yang akan mudah diingat oleh anak. Sebab anak usia dini, mereka belum memiliki kemampuan untuk melakukan hal yang abstrak sehingga dalam mengenalkan huruf kepada anak harus dilakukan menggunakan hal yang konkrit sehingga anak akan mengenalkan konsep simbol dna bunyi huruf secara nyata, sehingga anak akan lebih mudah dalm mengingat dan memahami konsep tersebut.Mengajarkan anak dengan mengasosiasikan bunyi huruf menggunakan gerakan yang dicontohkan, akan membuat konsep tersebut menjadi sesuatu yang konkret.

Menurut Carol Seefelt dan Barbara A. Wasik dalam (Rahayuningsih et al., 2019) kemampuan mengenal huruf merupakan kemampuan anak dalam melakukan sesuatu atau kegiatan dengan cara mengenali ciri-ciri serta tanda dari sebuah aksara dalam tulisan yang menjadi bagian dari simbol huurf yang akan melambangkan bunyi dari bahasa. Kemampuan mengenal huruf menurut Papalia dalam (Rahayuningsih et al., 2019) merupakan fungsi simbolis (simbolic function) dimana anak memiliki kemampuan untuk menggunakan simbol, atau mengartikan sebuah kata, angka, serta gambar dari sebuah tempat seseorang melekatkan sebuah makna. 
Mengenalkan huruf pada anak usia dini merupakan hal yang paling mendasar serta penting melalui proses pengenalan terhadap simbol huruf, karena dalam mengenalkan metode membaca yang tidak memberikan beban kepada anak harus dilakukan dengan kegiatan pembelajaran dengan menggunakan bermain sehingga kegiatan menjadi menyenangkan.

Anak usia dini dalam Peraturan Kementrian Pendidikan Republik Indonesia 146 tahun 2014 (Kemendikbud, 2014) telah menetapkan indikator penguasaan pengenalan keaskaraan awal yaitu: anak mampu menunjukkan bentuk simbol huruf, anak mampu membuat sebuah gambaran dari beberapa coretan atau tulisan yang sudah menjadi bentuk huruf atau sebuah kata, anak mampu menuliskan namanya sendiri menggunakan simbol huruf.

Tujuan penelitian berdasarkan dari masalah tersebut yaitu untuk dapat mengetahui kemampuan mengenal huruf anak usia 5-6 tahun di perumahan guru, gg. bangau I, kelurahan soekarno hatta, kecamatan kotabumi selatan, kabupaten lampung utara.

\section{METODE}

Penelitian ini menggunakan jenis metode penelitian kualitatif deskriptif yang dirancang untuk mendeskripsikan kemampuan mengenal huruf anak usia 56 tahun. Subjek dipilih menggunakan teknik sampel nonprobability sampling yaitu purposive sample (pemilihan sample dengan pertimbangan tertentu). Kriteria pemilihan sampel yaitu: 1) Orangtua yang memiliki anak usia 5-6 tahun, 2) Orangtua yang tinggal di perumahan guru kotabumi selatan kabupaten lampung utara, 3) Anak usia 5-6 tahun yang tinggal di perumahan guru kotabumi selatan kabupaten lampung utara . Penelitian menggunakan 18 subjek yaitu anak-anak warga
Perumahan Guru, Gg. Bangau I, Kelurahan Soekarno Hatta, Kabupaten Lampung Utara yang berusia 5-6 tahun sebanyak 15 orang terdiri dari 7 orang anak laki-laki, 8 orang anak perempuan, dan 3 orang tua. Peneliti melakukan observasi dan wawancara terhadap beberapa orangtua dan anak usia 5-6 tahun di perumahan guru.

Penelitian ini menggunakan observasi dan wawancara untuk mengumpulkan data dengan proses analisis melalui tiga tahapan yaitu reduksi data, display data, dan kesimpulan serta verifikasi data. Reduksi data berarti merangkum, memilih data yang penting, memberikan kode dan membuang data yang tidak penting (Sugiyono, 2014). Display data atau penyajian data adalah memaparkan data yang sudah ada melalui tahapan reduksi sehingga akan memungkinkan adanya penarikan kesimpulan dan pengambilan tindakan (Sugiyono, 2014). Kesimpulan dan verifikasi data, merupakan penarikan kesimpulan dari hasil penelitian yang akan menjawab fokus penelitian berdasarkan hasil analisis data (Sugiyono, 2014).

Data observasi diperoleh melalui kegiatan observasi menggunakan pedoman penelitian pada variabel kemampuan mengenal huruf.Data wawancara diperoleh melalui wawancara mendalam dengan orangtua anak dengan menanyakan tentang kemampuan mengenal huruf pada anak usia dini, program atau kegiatan yang dilakukan untuk mengenalkan huruf pada anak, lingkungan pola asuh yang dilakukan dan sarana serta prasarana yang disediakan untuk mengenalkan huruf kepada anak. Wawancara mendalam dengan orangtua dilengkapi dengan hasil dari observasi dengan anak. Data yang tidak sesuai dengan fokus penelitian dihilangkan atau dibuang dan data yang dianalisis serta dijabarkan menggunakan pendekatan 
deskriptif. Penelitian dilakukan pada bulan Desember 2020 terhadap anak usia 5-6 tahun dan orang tua anak di Perumahan Guru, Gg. Bangau I, Kelurahan Soekarno Hatta, Kabupaten Lampung Utara terdiri dari terdiri dari7 orang anak laki-laki berinisial MAGA, APA, MII, IFH, ARR, MF, MAA8 orang anak perempuan berinisial NRP, NS, NA, KSN, FNA, EAZ, NKS, YZ dan 3 orang tua berinisial FR, E, dan FM. Berikut bagan penelitian yang akan dilakukan oleh peneliti.

\section{HASIL DAN PEMBAHASAN}

Penelitian ini ingin mengetahui kemampuan mengenal huruf yang dimiliki anak usia 5-6 tahu di Perumahan Guru, Gg. Bangau I, Kelurahan Soekarno Hatta, Kabupaten Lampung Utara. Dalam penelitian ini kemampuan mengenal huruf pada anak usia 5-6 tahun dilihat setelah dilakukan pembelajaran mengenal huruf. Ketentuan dari perolehan nilai yang diukur menggunakan hasil observasi dengan indikator kriteria kinerja 1) Kriteria sangat baik, yaitu apabila anak memperoleh nilai pengukuran kemampuan mengenal huruf antara $76-100 \%$, 2) Kriteria baik, yaitu apabila hasil penilaian kemampuan mengenal huruf yang diperoleh anak antara 56-75\%, 3) Kriteria cukup, yaitu apabila hasil penelitian kemampuan mengenal huruf yang diperoleh anak antara $41-55 \%$, 4) Kriteria kurang, yaitu apabila hasil penelitian kemampuan mengenal huruf yang diperoleh anak antara 0-40\%.

Dalam penelitian ini terdapat teknik analisis yaitu setiap data yang diperoleh dari hasil observasi akan dianalisis. Data yang diperoleh dalam penelitian ini merupakan mengetahui kemampuan mengenal huruf pada anak usia 5-6 tahun, analisis data menggunakan metode dan teknik analisis deskriptif kualitatif. Rumus yang akan digunakan menurut Anas Sudjono (Rahayuningsih et al., 2019) yaitu:

$$
P=\frac{F}{N} X 100 \%
$$

Keterangan:

$\mathrm{F}=$ frekuensi yang sedang dicari presentasenya

$\mathrm{N}=$ number of class (jumlah frekuensi)

$\mathrm{P}=$ Angka presentase

Berdasarkan observasi pada anak usia 5-6 tahun terdapat 15 anak yang menjadi subjek penelitian kememapuan mengenal huruf yang meliputi empat indikator yang menunjukkan kemampuan anak. Anak pertama yaitu anak berinisial NDP menunjukkan hasil sebanyak $77 \%$ menyatakan bahwa anak tergolong ke dalam kategori sangat baik, anak berinisial NS menunjukkan hasil sebanyak 95,8\% menyatakan bahwa anak tergolong ke dalam kategori sangat baik, anak berinisial MAGA menunjukkan hasil sebanyak 98,9\% menyatakan bahwa anak tergolong ke dalam kategori sangat baik, anak berinisial NA menunjukkan hasil sebanyak $84,3 \%$ menyatakan bahwa anak tergolong ke dalam kategori sangat baik, anak berinisial APA menunjukkan hasil sebanyak $81,2 \%$ menyatakan bahwa anak tergolong ke dalam kategori sangat baik, anak berinisial MII menunjukkan hasil sebanyak 94,79\% menyatakan bahwa anak tergolong ke dalam kategori sangat baik, anak berinisial IFH menunjukkan hasil sebanyak 90,6\% menyatakan bahwa anak tergolong ke dalam kategori sangat baik, anak berinisial ARR menunjukkan hasil sebanyak 95,8\% menyatakan bahwa anak tergolong ke dalam kategori sangat baik, anak berinisial MF menunjukkan hasil sebanyak $89,58 \%$ menyatakan bahwa anak tergolong ke dalam kategori sangat baik, anak berinisial MAA menunjukkan hasil sebanyak $93,75 \%$ menyatakan 
bahwa anak tergolong ke dalam kategori sangat baik, anak berinisial KSN menunjukkan hasil sebanyak 95,8\% menyatakan bahwa anak tergolong ke dalam kategori sangat baik, anak berinisial FNA menunjukkan hasil sebanyak 96,87\% menyatakan bahwa anak tergolong ke dalam kategori sangat baik, anak berinisial EAZ menunjukkan hasil sebanyak $88,54 \%$ menyatakan bahwa anak tergolong ke dalam kategori sangat baik, anak berinisial NKS menunjukkan hasil sebanyak 91,66\% menyatakan bahwa anak tergolong ke dalam kategori sangat baik, anak berinisial YZ menunjukkan hasil sebanyak 96,87\% menyatakan bahwa anak tergolong ke dalam kategori sangat baik. Berikut ini gambar kemampuan mengenal huruf dalam bentuk grafik 1 .

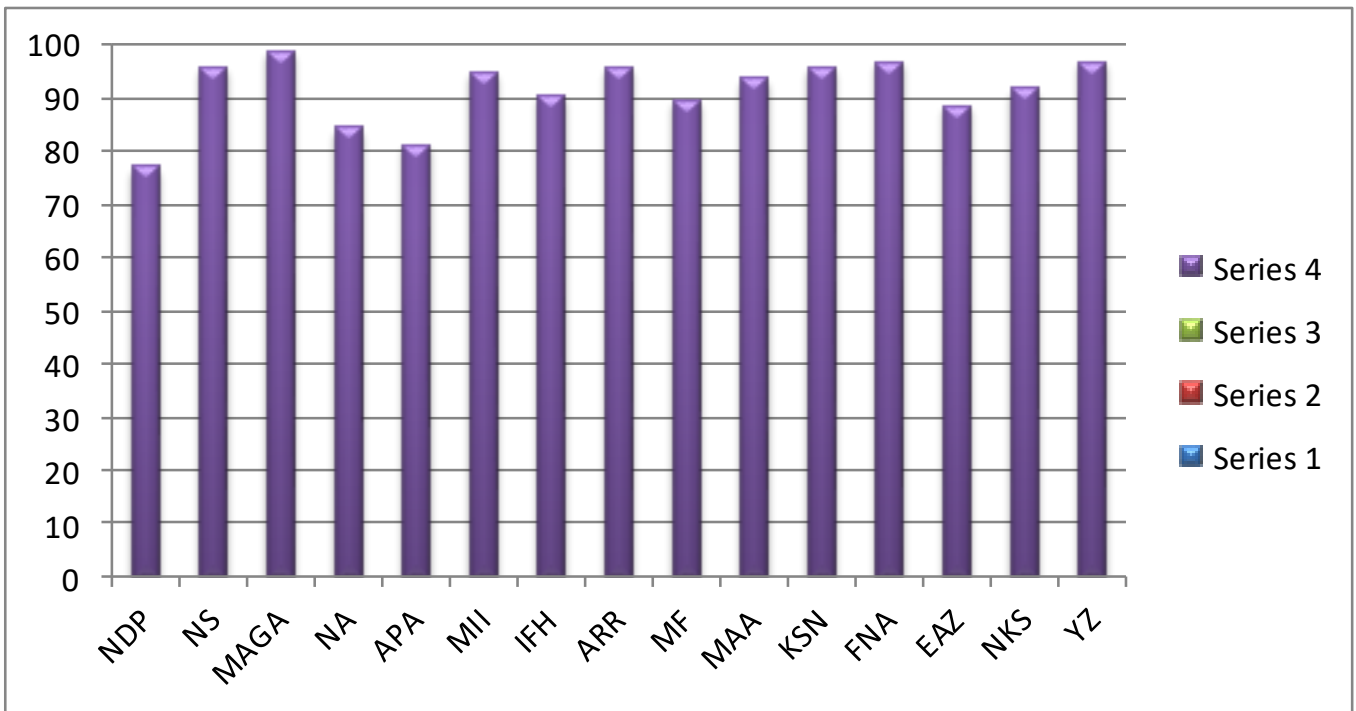

Gambar 1. Kemampuan Mengenal Huruf

\section{Pembahasan}

Berdasarkan pelaksanaan tindakan observasi dan wawancara yang meneunjukkan kemampuan mengenal huruf anak usia 5-6 tahun di Perumahan Guru, Gg. Bangau I, Kelurahan Soekarno Hatta, Kabupaten Lampung Utara. Penelitian ini menggunakan teknik deskriptif, sehingga data yang didapatkan terkumpul dalam bentuk lembaran observasi dan wawancara, dimana lembar observasi dihitung secara deskriptif dengan rumus yang telah ditentukkan untuk melihat presentase kemampuan mengenal huruf yang dimiliki oleh anak usia 5-6 tahun. Hasil observasi kemampuan mengenal huruf anak usia 56 tahun dari 15 anak yang diobservasi mencapai presentase $77 \%$ - $98,9 \%$ yang menyatakan bahwa anak tergolong ke dalam kategori sangat baik.

Anak usia dini dalam Peraturan Kementian Pendidikan Republik Indonesia $\quad 146 \quad$ tahun 2014 (Kemendikbud, 2014) telah menetapkan indikator penguasaan pengenalan keaskaraan awal yaitu: anak mampu menunjukkan bentuk simbol huruf, anak mampu membuat sebuah gambaran dari beberapa coretan atau tulisan yang sudah menjadi bentuk huruf atau sebuah kata, anak mampu menuliskan namanya sendiri menggunakan simbol huruf. Dalam mengenalkan huruf kepada anak usia dini akan lebih maksimal apabila diberikan dukungan guru dan orangtua, menurut Astuti dalam (Rahayuningsih et al., 2019) terdapat pengoptimalan 
kerjasama antara orang tua dan guru akan dapat membantu pertumbuhan dan perkembangan anak dengan sangat baik. "Menurut saya sebagai orang tua kemampuan mengenal huruf pada anak usia dini merupakan hal penting yang harus diajarkan dan dikenalkan kepada anak, karena sebelum anak mampu membaca dengan lancar anak harus mengenal setiap huruf baik dari bagaimana bentuk, bunyi, dan ciri dari setiap huruf, sehingga kemampuan mengenal huruf pada anak usia dini merupakan hal yang wajib dimiliki oleh anak, akan menjadi hal mendasar sebelum anak diajarkan untuk membaca dengan baik dan benar".

Kemampuan mengenal huruf pada anak menurut Papalia dalam (Rahayuningsih et al., 2019) merupakan fungsi simbolis (simbolic function)dimana anak memiliki kemampuan untuk menggunakan simbol, atau mengartikan sebuah kata, angka, serta gambar dari sebuah tempat seseorang melekatkan sebuah makna.

"Program atau kegiatan khusus untuk mengenalkan huruf kepada anak saya biasa saya membantu anak saya mengerjakan tugas atau buku yang diberikan sekolahnya, disana terdapat huruf mengajarkan anak saya menulis huruf, menanyakan setiap huruf, mengajarkan bunyi huruf $A-Z$, saya juga sering bertanya kepada anak secara acak ini huruf apa, jika dia tahu maka saya akan membenarkan, jika anak menjawab tidak tahu maka akan saya beritahu cirinya dan bunyinya seperti apa, untuk program atau kegiatan khusus tidak ada waktu khusus untuk mengajarkan anak pada pengenalan huruf, saya sering mengajak anak untuk bernyanyi lagu "ABCD" baik dalam bahasa indonesia maupun lagu dalam bahasa asing seperti bahasa inggris, saya juga melakukan kegiatan seperti mengajarkan tulisan nama dirinya sendiri, nama orang yang ada disekitarnya, namun untuk mengenalkan satu persatu setiap lambang huruf belum ada program atau kegiatan khusus yang saya lakukan, saya juga sering membacakan dongeng sebelum anak tidur itupun tidak dilakukan setiap malam, hanya jika saya ingat dan ingin membacakan saja, anak saya juga sering menonton televisi dan mendapatkan banyak kosa kata baru dari tontonan yang saya pilihkan, saya mengajarkan kepada anak saya untuk menonton tontonan sesuai dengan usianya yaitu kartun atau animasi anak, anak saya juga gemar bertanya tentang bacaan yang ada dan meminta saya untuk membacakan".

Mengenalkan huruf pada anak usia dini merupakan hal yang paling mendasar serta penting melalui proses pengenalan terhadap simbol huruf, karena dalam mengenalkan metode membaca yang tidak memberikan beban kepada anak harus dilakukan dengan kegiatan pembelajaran dengan menggunakan bermain sehingga kegiatan menjadi menyenangkan.

"Dalam mengenalkan huruf kepada anak saya tidak memaksa anak harus mengenal huruf dengan cepat, saya sering mengulangi satu huruf dengan ciri, bunyi, dan bagaimana cara menulisnya beberapa saat, membutuhkan beberapa waktu hingga anak akan mampu memahami dan mengenal huruf tersebut, saya juga sering mengajak anak melakukan kegiatan yang diselingi dengan bermain yang disukainya namun ada konsep mengenalkan huruf, karena anak saya mudah bosan sehingga saya harus melekukan kegiatan dengan cara memilih beberapa permainan agar anak tertarik untuk belajar mengenal huruf, mengenalkan huruf kepada anak saya melakukan aktivitas seperti sering mangajak anak berbicara menggunakan bahasa indonesia yang baik, mengenalkan huruf A-Z kepada anak melalui kegiatan menulis di kertas". 
Hasil wawancara dengan orang tua menunjukkan bahwa dalam mengenalkan huruf kepada anak dapat menggunakan sarana dan prasana dalam mengenalkan huruf kepada anak usia dini di rumah agar cara menarik minat anak dalam mengenal huruf.

"Sarana dan prasarana dalam mengenalkan huruf kepada anak usia dini di rumah, saya menyediakan beberapa buku bacaan yang sesuai dengan usia anak, beberapa buku tulis untuk mengenal huruf anak usia dini. Sarana dan prasarana yang saya sediakan untuk mengenalkan huruf kepada anak saya, biasanya saya menggunakan buku bergambar huruf, buku bercerita, mendengarkan lagu, bermain huruf melalui kartu huruf. Cara yang saya gunakan untuk menarik minat anak dalam mengenal huruf dengan mengajak anak bernyanyi, mengajak anak belajar bersama dengan menulis di buku tulis khusus mengenal huruf, dan mengajak anak membaca buku bacaan sambil bercerita, bertanya, dan berpendapat. Menarik minat anak dalam mengenal huruf biasanya saya mengikut sertakan anak langsung dalam kegiatan, saya biasanya melakukan pengenalan huruf dengan bermain sehingga anak saya belajar mengenal huruf tanpa paksaan".

Kemampuan mengenal huruf pada anak merupakan hasil dari pola asuh, pembiasaan, dan mengenalkan anak secara langusng dengan huruf, hasil dari kesiapan anak dalam mengenal setiap huruf dan bagaimana orang tua dapat menarik perhatian anak dalam mengenal setiap simbol, bentuk, dan bunyi huruf yang berbeda-beda, sehingga anak akan memiliki kesiapan untuk memasuki tahap selanjutnya yaitu membaca serta menerjemahkan kalimat.

\section{SIMPULAN}

Berdasarkan hasil penelitian melalui observasi dan wawancara yang dilakukan, dapat diambil simpulan bahwa kemampuan mengenal huruf pada anak usia 5-6 tahun di di Perumahan Guru, Gg. Bangau I, Kelurahan Soekarno Hatta, Kabupaten Lampung Utara tergolong ke dalam kategori sangat baik. Hal ini dapat dibuktikan berdasarkan hasil presentase observasi yang menunujukkan kemampuan mengenal huruf anak usia 56 tahun dari 5 anak yang diobservasi mencapai presentase $77 \%-98,9 \%$ yang menyatakan bahwa anak tergolong ke dalam kategori sangat baik.Dari hasil wawancara dapat disimpulkan kemampuan mengenal huruf merupakan salah satu tahapan paling dasar atau awal sebelum anak memasuki tahapan membaca, dalam mengenalkan huruf melalui metode membaca yang tidak memberikan beban kepada anak harus dilakukan dengan kegiatan pembelajaran dengan menggunakan bermain sehingga kegiatan menjadi menyenangkan, anak mampu menunjukkan bentuk simbol huruf, anak mampu membuat sebuah gambaran dari beberapa coretan atau tulisan yang sudah menjadi bentuk huruf atau sebuah kata, anak mampu menuliskan namanya sendiri menggunakan simbol huruf. Dalam mengenalkan huruf kepada anak usia dini akan lebih maksimal apabila diberikan dukungan guru dan orang tua terdapat pengoptimalan kerjasama antara orang tua dan guru akan dapat membantu pertumbuhan dan perkembangan anak dengan sangat baik menggunakan sarana dan prasarana yang mendukung anak dalam mengenal huruf.

Berdasarkan penelitian yang sudah dilakukan, penelitian memberikan saran sebagai berikut.

1. Bagi orang tua: Orang tua dapat memaksimalkan pengenalan huruf kepada anak dengan mengembangkan 
media dan metode yang digunakan dengan menarik dan kreatif agar mampu mengembangkan kemampuan anak secara maksimal.

2. Bagi peneliti selanjutnya: Hasil penelitian ini dapat dijadikan referensi untuk penelitian selanjutnya yang terkait dengan kemampuan mengenal huruf pada anak usia 5-6 tahun.

\section{REFERENSI}

Kemendikbud. (2014). Permen Kemendikbud No. 146 Tahun 2014 Tentang Kurikulum 2013 Pendidikan Anak Usia Dini. Permen Kemendikbud, 2025(1679). https://portaldik.id/assets/upload/per aturan/Permen Kemendikbud Nomor 146 Tahun 2014 Kurikulum 2013 Pendidikan Anak Usia Dini.pdf

Khadijah. (2016). Pengembangan Kognitif Anak Usia Medan: Perdana. Publishing.

Mislahusnika. (2016).

Meningkatkan

Upaya

Mengenal Lambang Huruf Melalui
Permainan Pohon Huruf Pada Anak Usia Dini Di Paud Teratai Tahun Pelajaran 2016. Revista Brasileira de Ergonomia, 9(2), 10.

Nursalam, 2016, metode penelitian, \& Fallis, A. . (2013). Pengaruh Media Flash Card Terhadap Kemampuan Mengenal Huruf Pada Anak Kelompok A. Journal of Chemical Information and Modeling, 53(9), 1689-1699.

Rahayuningsih, S. S., Soesilo, T. D., \& Kurniawan, M. (2019). Peningkatan Kemampuan Mengenal Huruf Pada Anak Usia 5-6 Tahun Melalui Metode Bermain Dengan Media Kotak Pintar. Scholaria: Jurnal Pendidikan Dan Kebudayaan, 9(1), 11-18.

https://doi.org/10.24246/j.js.2019.v9 .i1.p11-18

Sugiyono. (2014). Metode Penelitian Pendidikan pendekatan Kuantitatif, Kualitatif dan R\&D. In Metode Penelitian Ilmiah.

Sujiono, Y.N. (2008). Konsep Dasar Pendidikan Anak Usia Dini. 121. 